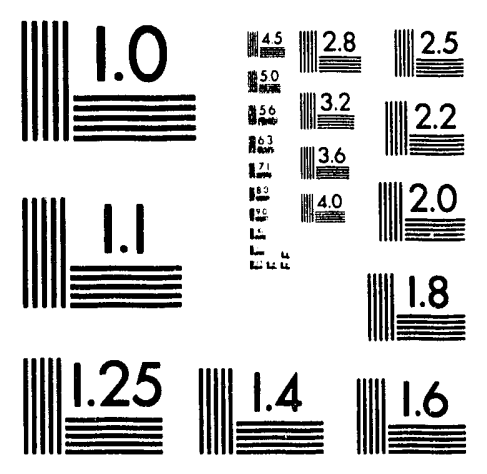



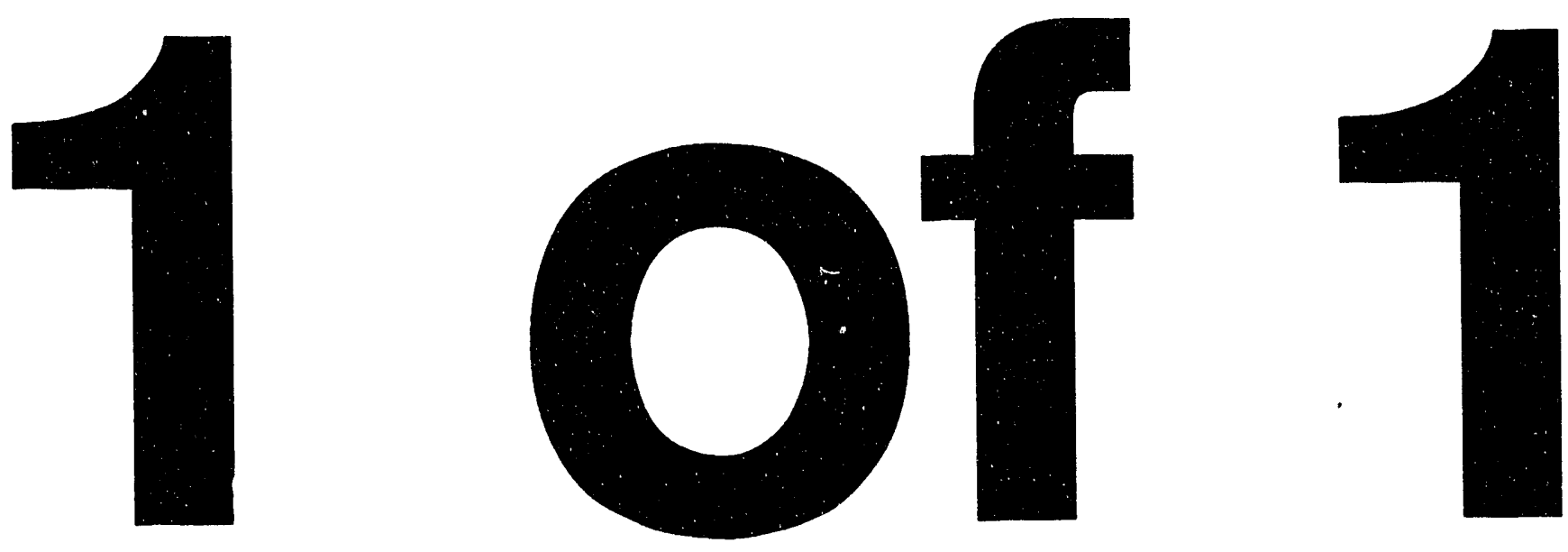


\section{National Emission Standards for Hazardous Air Pollutants Application for Approval to Construct Rotary Mode Core-Sampling Truck and Exhauster}

Date Published

May 1993

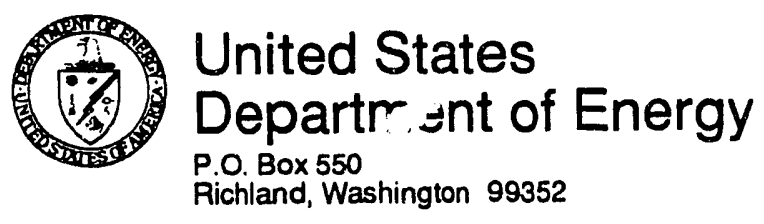


DOE/RL-93-39

This page intentionally left blank. 


\section{EXECUTIVE SUMMARY}

Characterization of wastes in the underground single-shell tanks and double-shell tanks on the Hanford Site is crucial in developing the final disposal options for the waste and closure strategy for the Hanford Site. Additionally, characterization of tank waste is important for the waste tank safety programs. The Hanford Federal Facility Agreement and Consent Order (also referred to as the Tri-Party Agreement) Milestone M-10-00 requires the obtaining and analyzing of at least two samples from each single-shell tank, and Milestone $M-10-13$ specifically requires the ability to sample hard saltcake. Existing equipment does not allow sampling of all single-shell tanks within established tank safety limits.

Consequently, the U.S. Department of Energy, Richland Operations Office has developed a rotary mode core-sampling system that uses nitrogen gas to cool and clear the drill bit. A rotary mcde core-sampling truck will be used on approximately 80 single-shell tanks which contain saltcake wastes, and will provide crucial information on the contents of the tanks. This application is a request for approval to construct and operate the rotary mode core-sampling truck and exhauster in the 200 East and 200 West Area Tank Farms of the Hanford Site. This request is being made pursuant to 40 CFR 61 , Subpart H. ${ }^{2}$

${ }^{1}$ Hanford Federal Facility Agreement and Consent Order, 2 vols., as amended, State of Washington Department of Ecology, U.S. Environmental Protection Agency, and U.S. Department of Energy, 01ympia, Washington, 1990.

${ }^{2} 40$ CFR 61, "National Emission Standards for Emissions of Radionuclide other than Radon from U.S. Department of Energy Facilities, "Subpart H, as amended, Code of Federal Regulations, 1991. 
DOE/RL-93-39

This page intentionally left blank. 


\section{CONTENTS}

1.0 PROPOSED NATURE OF THE SOURCE . . . . . . . . . . . . . . . . . . 1

2.0 PROPOSED SIZE OF THE SOURCE . . . . . . . . . . . . . . . . . . . . 1

3.0 PROPOSED DESIGN OF THE SOURCE . . . . . . . . . . . . . . . . . . . 2

4.0 OPERATING DESIGN CAPACITY . . . . . . . . . . . . . . . . . . . . 2

5.0 METHOD OF OPERATION . . . . . . . . . . . . . . . . . . . . . . . 2

6.0 EMISSIONS CONTROL SYSTEM . . . . . . . . . . . . . . . . . . . 3

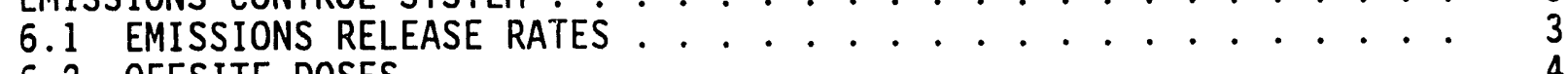

6.2 OFFSITE DOSES . . . . . . . . . . . . . . . . . . . . . . 4

7.0 REFERENCES . . . . . . . . . . . . . . . . . . . . . . . . . . 9

APPENDIX:
A. PRELIMINARY TANK ORDER . . . . . . . . . . . . . . . . . . A-1

\section{LIST OF FIGURES}

1 Design Drawing of Exhaust System . . . . . . . . . . . . . . . . 2

\section{LIST OF TABLES}

1 Average Rotary Mode Tank Emissions . . . . . . . . . . . . . . . . . 5

2 High Cesium-137 Tank Emissions . . . . . . . . . . . . . . . . . . 6

3 High Strontium-90 Tank Emissions . . . . . . . . . . . . . . . . . . . 7

4 Offsite Dose . . . . . . . . . . . . . . . . . . . . . . 8 
DOE/RL-93-39

\section{ACRONYMS}

EDE effective dose equivalent

EPA U.S. Environmental Protection Agency

HEPA high-efficiency particulate air

SST single-shell tank 


\section{NATIONAL EMISSION STANDARD FOR HAZARDOUS AIR POLLUTANTS APPLICATION FOR APPROVAL TO CONSTRUCT ROTARY MODE CORE-SAMPLING TRUC? AND EXHAUSTER}

\subsection{PROPOSED NATURE OF THE SOURCE}

Efforts have been ongoing to obtain core samples from the contents of each of the Hanford Site's 149 single-shell tanks (SST). The SSTs contain various amounts and combinations of liquid, sludge, and saltcake. Existing sampling equipment is unable to (within established tank safety restrictions [particularly limits on temperature]) retrieve samples of wastes that have hardened.

A new rotary mode core-sampling system has been designed to sample tanks containing hardened wastes. The prominent feature of this new system is the use of a nitrogen gas purge. The nitrogen gas purge will cool the drill bit and prevent cross contamination of different waste layers in the tank. The nitrogen gas purge will also allow more complete sample recovery by clearing cuttings that might otherwise obstruct the sampler or drill bit. Nitrogen was chosen over other compressed gases for its inherent safety.

Many of the tanks to be sampled with the rotary mode core-sampling system are not actively ventilated: they are operated at atmospheric pressure with passive (i.e., breather) high-efficiency particulate air (HEPA) filters. Unless a ventilation system of the proper capacity is used, addition of the nitrogen purge gas to SSTs will cause the tanks to pressurize. Additionally, the use of the rotary mode core-sampling system will generate aerosols and dusts potentially containing radioactive particles in the tank vapor space.

Consequently, an exhauster will be required during operation of the rotary mode core-sampling system on SSTs to prevent tank pressurization and to control emissions. This exhauster will be required to be moved from tank farm to tank farm with the system. In accordance with the U.S. Environmental Protection Agency's (EPA) definition of a stationary source, each time the exhaustier is moved between tank farms on the Hanford Site, approval would be required before the "construction" of the source. The U.S. Department of Energy, Richland Operations Office requests that the EPA provide approval to operate the exhauster in all tank farms within the 200 East and 200 West Areas of the Hanford Site, without requiring further approvals each time the exhauster is moved in support of the characterization efforts.

\subsection{PROPOSED SIZE OF THE SOURCE}

The source would consist of an approximately $5.6 \pm 1.4 \mathrm{~m}^{3} / \mathrm{min}$ $\left(200 \pm 50 \mathrm{ft}^{3} / \mathrm{min}\right)$ exhaust system connected to a riser on one of 80 SSTs which require rotary mode core sampling. The sampling system would be connected to a second riser on the tank. 


\subsection{PROPOSED DESIGN OF THE SOURCE}

The conceptual design of the exhauster system (i.e., control equipment, fan, and stack) is shown in Figure l. The first part of the exhauster system consists of an in-riser prefilter, which can be backwashed into the tank, to remove most of the larger particles and aerosols generated as a part of the rotary mode core-sampling. The second part consists of two testable HEPA filters in series, preceded by a prefilter in the HEPA filter housing. This second part is designed to remove the smaller particles, including particulate radionuclides. The fan and stack complete the exhauster system. The stack will be equipped with sampling equipment designed and operated in accordance with 40 CFR 61 , Subpart $H$, and al1 referenced requirements. Additionally, the stack will contain detectors for both volatile organic compounds and ammonia.

The system has been designed to allow safe sampling in all of the SSTs at the Hanford Site, including those on various watchlists (e.g., ferrocyanide watchlist tanks) which are among many of the first tanks scheduled to be sampled. (Watchlist tanks have been identified in accordance with 42 U.S.C. 7274. These tanks contain most of the conditions that could lead to an uncontrolled release of fission products.)

\subsection{OPERATING DESIGN CAPACITY}

The fan will operate at approximately $5.6 \pm 1.4 \mathrm{~m}^{3} / \mathrm{min}(200$

$\left.\pm 50 \mathrm{ft}^{3} / \mathrm{min}\right)$. Approximately 15 tanks could be sampled each year, based on the current, aggressive schedule. Each tank will take approximately 1 month to sample. This includes setup and breakdown time, in addition to the time required to move the rotary mode core sample truck for connection to two risers at each tank, which will allow two complete cores to be taken.

\subsection{METHOD OF OPERATION}

After the exhaust system and rotary mode core sample system are connected to the tank to be sampled, and all required preoperational tests are complete, rotary mode core-sampling will progress. (Pre-operational tests include sampling of the vapor space for toxic air pollutants.) An attempt will first be made to core-sample the waste using push mode. When instrumentation indicates that hard waste has been reached, the exhauster will be started and the drill bit will start rotating. Whenever the drill bit is rotating, njtrogen gas will be injected into the drill string at approximately 1.4 $\mathrm{m}^{3} / \mathrm{min}\left(50 \mathrm{ft}^{3} / \mathrm{min}\right)$ to a maximum of $2.8 \mathrm{~m}^{3} / \mathrm{min}\left(100 \mathrm{ft}^{3} / \mathrm{min}\right)$. Each $48.3-\mathrm{cm}$ (19-in.) segment requires drilling for 5 to $20 \mathrm{~min}$. While the sampler is being changed out after each segment, nitrogen will be injected into the drill string at approximately $.03 \mathrm{~m}^{3} / \mathrm{min}\left(1 \mathrm{ft}^{3} / \mathrm{min}\right)$. This will maintain the hydrostatic head in the drill string (preventing waste from entering the space 
DOE/RL-93-39

Figure 1. Design Drawing of Exhaust System.

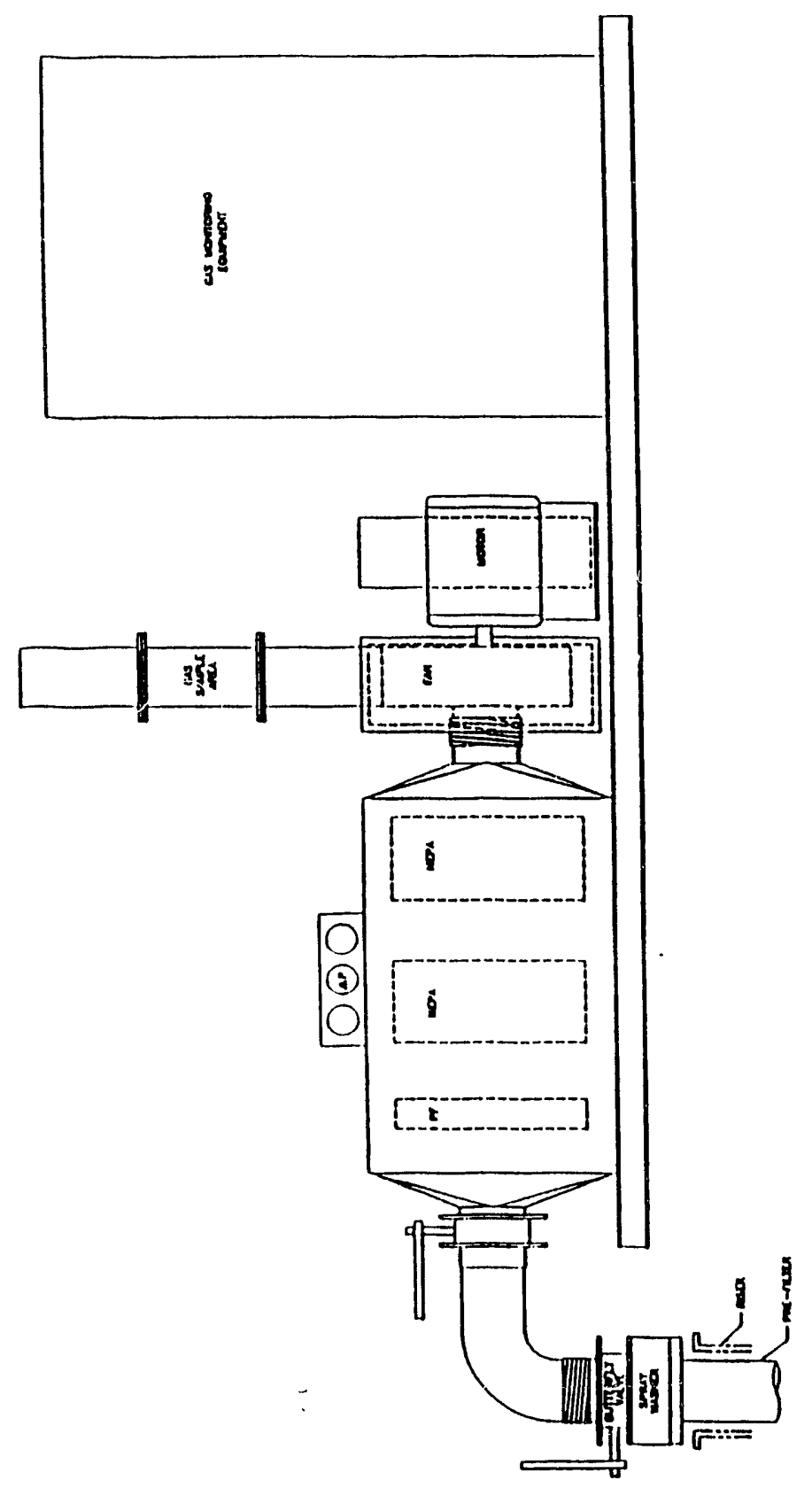


just sampled) and allows for pressurization and depressurization of the sample receiver as necessary for sampler changeout. The exhauster will be operated only when sampling activities are underway (i.e., one or two 8-hour shifts of actual sampling each day).

Once a complete core has been obtained, the position of the rotary mode core-sampling truck will be changed. The rotary mode core-sampling truck will either be repositioned at the same riser, or moved to a different riser on the same tank, to allow a second core to be obtained. Upon completion of the second core, the exhauster and rotary mode core-sampling systems will be disconnected and moved to the next tank to be sampled. During sampler and exhauster connection and disconnection, as-10w-as-reasonably-achievable principles will be followed including minimizing the time the riser is left open.

When possible, movement of the exhauster and rotary mode core-sampling systems between tank farms will be 1 imited. This will not always be possible because numerous issues cuntribute ${ }^{+} 0$ determining the order of tank sampling. The first 30 tanks to be sampled using the rotary mode core-sampling system have been identified. Appendix A contains a preliminary list, which is subject to revision with changing priorities.

A sampling system compliant with the applicable requirements of 40 CFR 61 Subpart $H$ will be installed in the stack for the exhauster.

\subsection{EMISSIONS CONTROL SYSTEM}

Particulate radioactive emissions are of primary concern from the rotary mode core-sampling activities. The in-riser prefilter and prefilter/HEPA filter sections of the exhaust system are designed to remove both 7 arge and small particles from the air stream. The in-riser prefilter will control the larger particles, and allow them to be washed back into the tank. The prefilter/HEPA section will be testable to ensure that 99.95 percent of the particles greater than $0.3 \mu \mathrm{m}$ in size will be removed from the air stream.

As further information is available on the emissions resulting from the operation of the rotary mode core-sampling system (particularly, filter loading), the appropriateness of the exhauster and control system will be verified and additional controls added, as necessary.

\subsection{EMISSIONS RELEASE RATES}

The exact contents of the SSTs is not known, which is why the rotary mode core-sampling system was designed to provide more information on tank conterits. Unfortunately, that makes determining the source term of the tanks difficult: Several methods were used to try to bound the emissions as a result of the rotary mode core-sampling activities. Those methods included process knowledge, computer modeling, and testing of stimulants.

As a result of computer modeling and tests conducted on waste stimulants, an upper bound aerosol generation rate of $1 \mathrm{~kg}(2.2 \mathrm{lb}) /$ core was determined. 
This assumes that there is little open dome space and the waste is dry. The documentation for this simulation is currently being revised arid will be provided when available.

Three sets of estimates of tank waste radionuclide concentration were used to determine the upper bound release rates resulting from rotary mode core-sampling: (1) the average of all tanks to be rotary mode sampled, (2) the tank with the highest expected concentration of ${ }^{137} \mathrm{Cs}$

(i.e., Tank 241-S-112), and (3) the tank with the expected highest concentration of ${ }^{90} \mathrm{Sr}$ (Tank 241-A-101). Each tank will have 2 cores sampled, and 15 tanks are assumed to be sampled each year. Table 1 includes the concentration of radionuclides in the "average tank" waste, the quantity of each isotope released to the emission control system for each core (i.e., unabated emission), the emissions from the exhaust system for each core (i.e., abated emissions), and the annual emissions (abated) from the average tank. To calculate abated emissions, a control efficiericy of 99.95 percent was assumed for radionuclides in the particulate form. A wide variety of isotopes are possible in the tank waste, but only those isotopes which would contribute at least 0.0001 percent of the unabated dose from the average tank are included in the table. Tables 2 and 3 provide the same information for the high cesium, and high strontium tanks, respectively, including all of the isotopes listed for the average tank. For the high cesium and high strontium tanks the isotopes 1 isted contribute more than 0.0001 percent of the unabated dose.

\subsection{OFFSITE DOSES}

Table 4 provides the offsite doses corresponding to the emissions shown in Tables 1 through 3 . The unit dose factors provided in the table were developed previously and can be found in WHC-EP-0498 ( $\because H C$ 1991). This document provided the effective dose equivalent (EDE) to the hypothetical maximally exposed offsite individual from each of the major areas on the Hanford Site for the most commoniy encountered radioactive isotopes. It is assumed, for conservatism, that all of the tanks sampled are located in the 200 East Area. Emissions from the 200 East Area result in larger offsite doses, because of the location of the hypothetical maximally exposed offsite individual ( $16 \mathrm{~km}$ [10 mi] east of 200 East, or $24 \mathrm{~km}$ [15 mi] east of 200 West). It should be noted that the annual dose provided for both the high cesium and high strontium cases assume that all the tanks sampled have the same concentration. This provides an upper bound limit on the offsite dose.

All of the offsite doses provided are less than $0.0006 \mathrm{mrem} / \mathrm{yr}$, to the hypothetical maximally exposed offsite individual. This value is highly conservative, to account for uncertainties in the contents of the tank waste and the variability in particles generated because of rotary mode coresampling efforts. The dose resulting from all Hanford Site operations in 1991 was calculated at $0.007 \mathrm{mrem} / \mathrm{yr}$ (PNL 1992). The emissions as a result of rotary mode core-sampling efforts, in conjunction with previous operations on the Hanford Site, will not result in a violation of the National Emission Standard of $10 \mathrm{mrem} / \mathrm{yr}$ (40 CFR 6l). 
Table 1. Average Rotary Mode Tank Emissions.

\begin{tabular}{|c|c|c|c|c|}
\hline Isotope & $\begin{array}{c}\text { Concentration } \\
\text { in tank waste } \\
(\mathrm{C} i / g)\end{array}$ & $\begin{array}{l}\text { Released to } \\
\text { control system, } \\
\text { each core } \\
\text { (unabated) } \\
\text { (Ci/core) }\end{array}$ & $\begin{array}{c}\text { Emitted, each } \\
\text { core (abated) } \\
\text { (Ci/core) }\end{array}$ & $\begin{array}{c}\text { Annual } \\
\text { emissions } \\
\text { (abated) } \\
(\mathrm{C} i / \mathrm{yr})\end{array}$ \\
\hline Sr-90* & $1.02 \mathrm{E}-04$ & $1.02 \mathrm{E}-01$ & $5.10 \mathrm{E}-05$ & $1.53 E-03$ \\
\hline Cs $-137^{*}$ & 9.02 E-05 & 9.02. E-02 & $4.51 E-05$ & $1.35 \mathrm{E}-03$ \\
\hline$A m-2 A 1$ & $7.61 \quad E-08$ & 7.61 E-05 & $3.80 \mathrm{E}-08$ & $1.14 \mathrm{E}-06$ \\
\hline $\mathrm{Pu}-239$ & 4.80 E-08 & 4.80 E-05 & $2.40 \mathrm{E}-08$ & $7.2 \quad E-07$ \\
\hline $\mathrm{Pu}-240$ & $1.12 \mathrm{E}-08$ & $1.12 \mathrm{E}-05$ & $5.60 \mathrm{E}-09$ & $1.68 \mathrm{E}-07$ \\
\hline Pu-238 & $2.91 \mathrm{E}-09$ & $2.91 \mathrm{E}-06$ & $1.45 \mathrm{E}-09$ & $4.36 \mathrm{E}-08$ \\
\hline $\mathrm{Pu}-241$ & $1.31 \mathrm{E}-07$ & $1.31 E-04$ & $6.55 E-8$ & $1.96 \mathrm{E}-06$ \\
\hline$U-238$ & $1.51 \mathrm{E}-09$ & $1.51 E-06$ & $7.55 E-10$ & $2.26 E-08$ \\
\hline$N p-237$ & $1.28 \mathrm{E}-10$ & $1.28 \mathrm{E}-07$ & $6.40 E-11$ & $1.92 \mathrm{E}-09$ \\
\hline $\mathrm{Cm}-244$ & $1.92 \mathrm{E}-1 \mathrm{U}$ & $1.82 \mathrm{E}-07$ & $9.10 \mathrm{E}-11$ & $2.73 \mathrm{E}-09$ \\
\hline$A m-243$ & $3.97 \mathrm{E}-11$ & $3.97 \mathrm{E}-08$ & $1.98 \mathrm{E}-11$ & $5.95 E-10$ \\
\hline$U-235$ & $6.42 \mathrm{E}-11$ & $6.42 \mathrm{E}-08$ & $3.21 \mathrm{E}-11$ & $9.63 E-10$ \\
\hline $\mathrm{Ni}-63$ & $5.22 \quad E-07$ & $5.22 \mathrm{E}-04$ & $2.61 \mathrm{E}-07$ & $7.83 \mathrm{E}-06$ \\
\hline$c-14$ & $3.04 \mathrm{E}-08$ & 3.04 E-05 & $3.04 \mathrm{E}-05$ & $9.12 E-04$ \\
\hline Tc-99 & $6.33 \mathrm{E}-08$ & 6.33 E-05 & $3.16 \mathrm{E}-08$ & $9.49 \mathrm{E}-07$ \\
\hline $\mathrm{Cm}-242$ & $8.01 \mathrm{E}-11$ & $8.01 E-08$ & $4.00 \mathrm{E}-11$ & $1.20 \mathrm{E}-09$ \\
\hline $1-129$ & $9.64 \mathrm{E}-11$ & $9.64 \mathrm{E} \cdots 08$ & $9.64 \mathrm{E}-08$ & $2.89 \mathrm{E}-06$ \\
\hline$S n-126$ & $1.25 E-09$ & $1.25 \mathrm{E}-06$ & $6.25 E-10$ & $1.87 E-08$ \\
\hline
\end{tabular}

*Daughter products included in calculation. 
Table 2. High Cesium-137 Tank Emissions.

\begin{tabular}{|c|c|c|c|c|}
\hline Isotope & $\begin{array}{c}\text { Concentration } \\
\text { in tank waste } \\
(\mathrm{C} i / g)\end{array}$ & $\begin{array}{l}\text { Released to } \\
\text { control system, } \\
\text { each core } \\
\text { (unabated) } \\
\text { (Ci/core) }\end{array}$ & $\begin{array}{c}\text { Emitted, each } \\
\text { core (abated) } \\
\text { (Ci/core) }\end{array}$ & $\begin{array}{l}\text { Annual } \\
\text { emissions } \\
\text { (abated) } \\
(\mathrm{C} i / \mathrm{yr})\end{array}$ \\
\hline $5 r-90^{*}$ & $1.89 \quad E-04$ & $1.89 E-01$ & $9.45 E-05$ & $2.83 E-03$ \\
\hline $\mathrm{Cs}-137^{\star}$ & $9.43 E-04$ & $9.43 E-0.1$ & 4.71 E-04 & 1.41 E-02 \\
\hline$A m-241$ & $1.89 \quad E-07$ & $1.89 \mathrm{E}-04$ & $9.45 E-08$ & $2.83 E-06$ \\
\hline $\mathrm{Pu}-239$ & $1.89 E-10$ & 1.89 E-07 & $9.45 \mathrm{E}-11$ & $2.83 E-09$ \\
\hline $\mathrm{Pu}-240$ & $3.88 \mathrm{E}-11$ & $3.88 \quad E-08$ & 1.94 E-11 & $5.82 E-10$ \\
\hline $\mathrm{Pu}-233$ & $5.66 E-11$ & $5.66 E-08$ & $2.83 E-i 1$ & $8.49 E-10$ \\
\hline $\mathrm{Pu}-241$ & $1.89 E-10$ & $1.89 \mathrm{E}-07$ & $9.45 E-11$ & $2.83 E-09$ \\
\hline$U-238$ & $3.77 \mathrm{E}-12$ & 3.77 E-09 & $1.88 E-12$ & $5.65 E-11$ \\
\hline $\mathrm{Np}-237$ & 7.54 E-10 & $7.54 \quad E-07$ & 3.77 E-10 & $1.13 E-08$ \\
\hline $\mathrm{Cm}-244$ & 9.43 E-10 & $9.43 E-07$ & $4.71 E-10$ & $1.41 \mathrm{E}-08$ \\
\hline$A m-243$ & $1.70 \mathrm{E}-10$ & $1.70 \quad E-07$ & $8.50 \mathrm{E}-11$ & $2.55 E-09$ \\
\hline$U-235$ & $1.32 \mathrm{E}-13$ & $1.32 E-10$ & $6.60 \mathrm{E}-14$ & $1.98 E-12$ \\
\hline $\mathrm{Ni}-63$ & $5.28 \quad E-07$ & $5.28 \quad E-04$ & $2.64 E-07$ & 7.92 E-06 \\
\hline$C-14$ & 1.89 E-07 & $1.89 \mathrm{E}-04$ & $1.89 E-04$ & $5.67 \mathrm{E}-03$ \\
\hline Tc-99 & 3.77 E-07 & $3.77 \mathrm{E}-04$ & $1.88 \quad E-07$ & $5.65 \mathrm{E}-06$ \\
\hline $\mathrm{Cm}-242$ & $1.89 E-10$ & $1.89 E-07$ & $9.45 \mathrm{E}-11$ & $2.83 E-09$ \\
\hline$I-129$ & $7.54 \mathrm{E}-10$ & $7.54 \mathrm{E}-07$ & $7.54 \quad E-07$ & 2.26 E-05 \\
\hline$S n-126$ & $1.89 E-10$ & $1.89 E-07$ & $9.45 E-11$ & $2.83 E-09$ \\
\hline
\end{tabular}

*Daughter products included in calculation.

${ }^{1}$ Assumes all 15 tanks have the same concentration. 
Table 3. High Strontium-90 Tank Emissions.

\begin{tabular}{|c|c|c|c|c|}
\hline Isotope & $\begin{array}{c}\text { Concentration } \\
\text { in tank waste } \\
\text { (Ci/g) }\end{array}$ & $\begin{array}{c}\text { Released to } \\
\text { control system, } \\
\text { each core } \\
\text { (unabated) } \\
\text { (Ci/core) }\end{array}$ & $\begin{array}{c}\text { Emitted, each } \\
\text { core (abated) } \\
\text { (Ci/core) }\end{array}$ & $\begin{array}{c}\text { Annual } \\
\text { emissions } \\
\text { (abated) } \\
\text { (Ci } / \text { yr) }\end{array}$ \\
\hline \hline $\mathrm{Sr}-90^{\star}$ & $3.78 \mathrm{E}-04$ & $3.78 \mathrm{E}-01$ & $1.89 \mathrm{E}-04$ & $5.67 \mathrm{E}-03$ \\
\hline $\mathrm{Cs}-13 \mathrm{~F}^{*}$ & $0.00 \mathrm{E}+00$ & $0.00 \mathrm{E}+00$ & $0.00 \mathrm{E}+00$ & $0.00 \mathrm{E}+00$ \\
\hline $\mathrm{Am}-241$ & $1.26 \mathrm{E}-07$ & $1.26 \mathrm{E}-04$ & $6.30 \mathrm{E}-08$ & $1.89 \mathrm{E}-06$ \\
\hline $\mathrm{Pu}-239$ & $2.52 \mathrm{E}-07$ & $2.52 \mathrm{E}-04$ & $1.26 \mathrm{E}-07$ & $3.78 \mathrm{E}-06$ \\
\hline $\mathrm{Pu}-240$ & $7.56 \mathrm{E}-08$ & $7.56 \mathrm{E}-05$ & $3.78 \mathrm{E}-08$ & $1.13 \mathrm{E}-05$ \\
\hline $\mathrm{Pu}-238$ & $1.01 \mathrm{E}-08$ & $1.01 \mathrm{E}-05$ & $5.05 \mathrm{E}-09$ & $1.51 \mathrm{E}-07$ \\
\hline $\mathrm{Pu}-241$ & $7.56 \mathrm{E}-07$ & $7.56 \mathrm{E}-04$ & $3.78 \mathrm{E}-07$ & $1.13 \mathrm{E}-05$ \\
\hline $\mathrm{U}-238$ & $8.82 \mathrm{E}-10$ & $8.82 \mathrm{E}-07$ & $4.41 \mathrm{E}-10$ & $1.32 \mathrm{E}-08$ \\
\hline $\mathrm{Np}-237$ & $5.04 \mathrm{E}-13$ & $5.04 \mathrm{E}-10$ & $2.52 \mathrm{E}-13$ & $7.56 \mathrm{E}-12$ \\
\hline $\mathrm{Cm}-244$ & $0.00 \mathrm{E}+00$ & $0.00 \mathrm{E}+00$ & $0.00 \mathrm{E}+00$ & $0.00 \mathrm{E}+00$ \\
\hline $\mathrm{Am}-243$ & $3.78 \mathrm{E}-11$ & $3.78 \mathrm{E}-08$ & $1.89 \mathrm{E}-11$ & $5.67 \mathrm{E}-10$ \\
\hline $\mathrm{U}-235$ & $3.78 \mathrm{E}-11$ & $3.78 \mathrm{E}-08$ & $1.89 \mathrm{E}-11$ & $5.67 \mathrm{E}-10$ \\
\hline $\mathrm{Ni}-63$ & $5.04 \mathrm{E}-06$ & $5.04 \mathrm{E}-03$ & $2.52 \mathrm{E}-06$ & $7.56 \mathrm{E}-05$ \\
\hline $\mathrm{C}-14$ & $0.00 \mathrm{E}+00$ & $0.00 \mathrm{E}+00$ & $0.00 \mathrm{E}+00$ & $0.00 \mathrm{E}+00$ \\
\hline $\mathrm{Tc}-99$ & $0.00 \mathrm{E}+00$ & $0.00 \mathrm{E}+00$ & $0.00 \mathrm{E}+00$ & $0.00 \mathrm{E}+00$ \\
\hline $\mathrm{Cm}-242$ & $1.01 \mathrm{E}-10$ & $1.01 \mathrm{E}-07$ & $5.05 \mathrm{E}-11$ & $1.51 \mathrm{E}-09$ \\
\hline $\mathrm{I}-129$ & $0.00 \mathrm{E}+00$ & $0.00 \mathrm{E}+00$ & $0.00 \mathrm{E}+00$ & $0.00 \mathrm{E}+00$ \\
\hline $\mathrm{Sn}-126$ & $3.78 \mathrm{E}-09$ & $3.78 \mathrm{E}-06$ & $1.89 \mathrm{E}-09$ & $5.67 \mathrm{E}-08$ \\
\hline
\end{tabular}

"Daughter products included in calculation.

${ }^{1}$ Assumes al1 15 tanks have the same concentration. 
Table 4. Offsite Dose.

\begin{tabular}{|c|c|c|c|c|}
\hline Isotope & $\begin{array}{l}\text { Unit EDE } \\
\text { factor, } \\
200 \text { East } \\
\text { (inrem } / \mathrm{Ci} \text { ) }\end{array}$ & $\begin{array}{l}\text { Annual EDE, } \\
\text { average tank } \\
\text { (mrem } / y r)\end{array}$ & $\begin{array}{c}\text { Annual EDE, } \\
\text { high }{ }^{137} \mathrm{Cs} \text { tank } \\
\text { (mrem/yr) }\end{array}$ & $\begin{array}{l}\text { Annual EDE, } \\
\text { high }{ }^{90} \mathrm{Sr} \text { tank } \\
\text { (mrem/yr) }\end{array}$ \\
\hline $5 r-90$ & $4.4 E-02$ & $6.70 \mathrm{E}-05$ & $1.24 E-04$ & $2.48 \mathrm{E}-04$ \\
\hline$C s-137$ & $2.4 E-02$ & $3.23 \mathrm{E}-05$ & $3.38 E-04$ & $0.00 E+00$ \\
\hline$A m-241$ & $1.3 E+01$ & $1.50 E-05$ & $3.71 E-05$ & $2.48 \quad E-05$ \\
\hline$P u-239$ & $8.7 E+00$ & $6.24 E-06$ & $2.46 E-08$ & $3.28 E-05$ \\
\hline$P u-240$ & $8.7 E+00$ & $1.45 \mathrm{E}-06$ & $5.04 E-09$ & 9.82 E-06 \\
\hline $\mathrm{Pu}-238$ & $8.0 E+00$ & $3.5 \quad E-07$ & $6.81 E-09$ & $1.22 \mathrm{E}-06$ \\
\hline $\mathrm{Pu}-241$ & $1.4 \mathrm{E}-01$ & $2.71 E-07$ & $3.91 E-10$ & 1.56 E-06 \\
\hline$U-238$ & $2.8 E+00$ & $6.46 E-08$ & $1.61 \mathrm{E}-10$ & $E-76 \quad E-08$ \\
\hline $\mathrm{Np}-237$ & $1.2 E+01$ & $2.28 E-08$ & $1.35 E-07$ & $9.00 \mathrm{E}-11$ \\
\hline $\mathrm{Cm}-244$ & $6.9 E+00$ & $1.89 E-08$ & $9.82 E-018$ & $0.00 E+00$ \\
\hline$A m-243$ & $1.3 E+01$ & $7.8 \quad E-09$ & $3.34 E-08$ & 7.43 E-09 \\
\hline$U-235$ & $3.0 E+00$ & $2.85 E-09$ & $5.86 E-12$ & $1.68 E-09$ \\
\hline $\mathrm{Ni}-63$ & $2.0 E-04$ & $1.59 E-09$ & $1.61 E-09$ & $1.54 E-08$ \\
\hline$C-14$ & $2.6 E-03$ & $2.39 E-06$ & $1.49 \mathrm{E}-05$ & $0.00 E+00$ \\
\hline Tc-99 & $1.1 E-03$ & $1.03 \quad E-09$ & $6.16 \mathrm{E}-09$ & $0.00 E+00$ \\
\hline $\mathrm{Cm}-242$ & 4.2 E- 01 & $5.10 \mathrm{E}-10$ & $1.2 \quad E-09$ & $6.43 \mathrm{E}-10$ \\
\hline$I-129$ & $2.9 \mathrm{E}-01$ & 8.42 E-07 & $3.25 E-06$ & $0.00 E+00$ \\
\hline$S n-126$ & $8.6 E-03$ & $1.62 \mathrm{E}-10$ & $2.45 \mathrm{E}-11$ & $4.89 E-10$ \\
\hline Total & & $1.26 E-04$ & $5.21 E-04$ & $3.19 E-04$ \\
\hline
\end{tabular}

$E D E=$ Effective dose equivalent. 


\subsection{REFERENCES}

Ecology, EPA, and DOE, 1990, Hanford Federal Facility Agreement and Consent Order, 2 vols., as amended, State of Washington Department of Ecology, U.S. Environmental Protection Agency, and U.S. Department of Energy, Richland, Washington.

PNL, 1992, Hanford Site Environmental Report for Calendar Year 1991, PNL 8148, Pacific Northwest Laboratory, Richland, Washington.

WHC, 1991, Unit Dose Calculation Methods and Summary of Facility Effluent Moritoring Plan Determinations, WHC-EP-0498, Westinghouse Hanford Company, Richland, Washington.

40 CFR 61, 1991, "National Emissions Standards for Hazardous Air Pollutants (NESHAP)," Code of Federal Regulations, as amended.

National Defense Authorization Act for Fiscal Year 1991, Section 3137, "Safety Measures for Waste Tanks at Hanford Nuclear Reservation," as amended, 42 U.S.C. 7274, et seq. 
DOE/RL-93-39

APPENDIX A

PRELIMINARY TANK ORDER

A-1 
DOE/RL-93-39

This page intentionally left blank. 


\section{APPENDIX A}

\section{PRELIMINARY TANK ORDER}

A preliminary list of the first 30 tanks to be sampled utilizing the rotary mode core-sampling system is provided below. It should be noted that this list is subject to revision based on changing priorities at the Hanford Site.

Tank 241-BY-104

Tank 241-BY-110

Tank 241-BY-107

Tank 241-BY-105

Tank 241-BY-103

Tank 241-BY-112

Tank 241-U-106

Tank 241-TY-103

Tank 241-BY-106

Tank 241-BY-101

Tank 241-TY-101

Tank 241-U-107

Tank 241-S-110

Tank 241-TX-105

Tank 241-SX-103
Tank 241-SX-101

Tank 241-BX-110

Tank 241-SX-105

Tank 241-AW-106

Tank 241-SX-106

Tank 241-S-112

Tank 241-BX-111

Tank 241-SX-104

Tank 241-BY-111

Tank 241-U-102

Tank 241-A-101

Tank 241-TX-118

Tank 241-SX-102

Tank 241-BY-108

Tank 241-AX-101

The A, AW, AX, BX, and BY Tank Farms are located in the 200 East Area while the S, SX, TX, TY, and U Tank Farms are located in the 200 West Area. 
DOE/RL-93-39

This page intentionally left blank. 
$\mathrm{DOE} / \mathrm{RL}-93-39$

\section{DISTRIBUTION}

Number of copies

OFFSITE

1

U.S. Environmental Protection Agency Air and Toxics Divisien

Region $X$

1200 Sixth Avenue

Seattle, WA 98101

Jim McCormick, Director

AT-082

\section{ONSITE}

5

U.S. Department of Energy-

Richland Operations Office

J. M. Clark

A4-02

P. R. Hernandez

A4-02

E. M. Matt 1 in

S. D. Stites

A4-02

Public Reading Room

A5-15

Al-65

Pacific Northwest Laboratory

Technical Library

$K 1-11$

21

Westinghouse Hanford Company

B. A. Aust in

B2-35

J. A. Bates

F. 0. Grey

D. B. Hagmann

G. W. Jackson

J. R. Kasper

R. J. Landon

J. J. Luke

P. J. Mackey

M. J. Minette

R. W. Oldham

D. N. Price

J. D. Robinson

H6-22

A2-24

S2-46

H6-21

R2-50

H6-22

H6-25

B3-15

S2-46

H6-25

R2-14

C. E. Sowa (3)

H5-09

H6-25

W. F. Zuroff

CES File/LB

Document Processing and Control

R2-14

H6-25

EDMC

L8-13

Information Release Administration

H6-08

A3-36 
DOE/RL-93-39

This page intentionally left blank. 

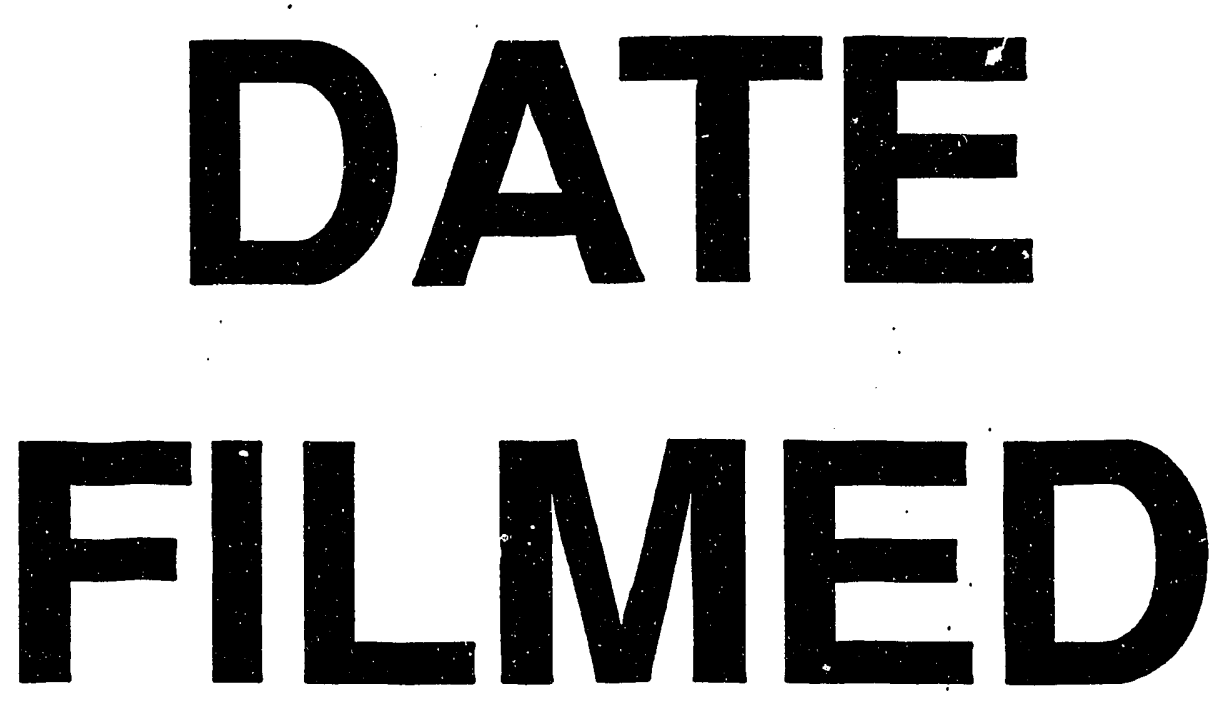

$10 / 13 / 93$
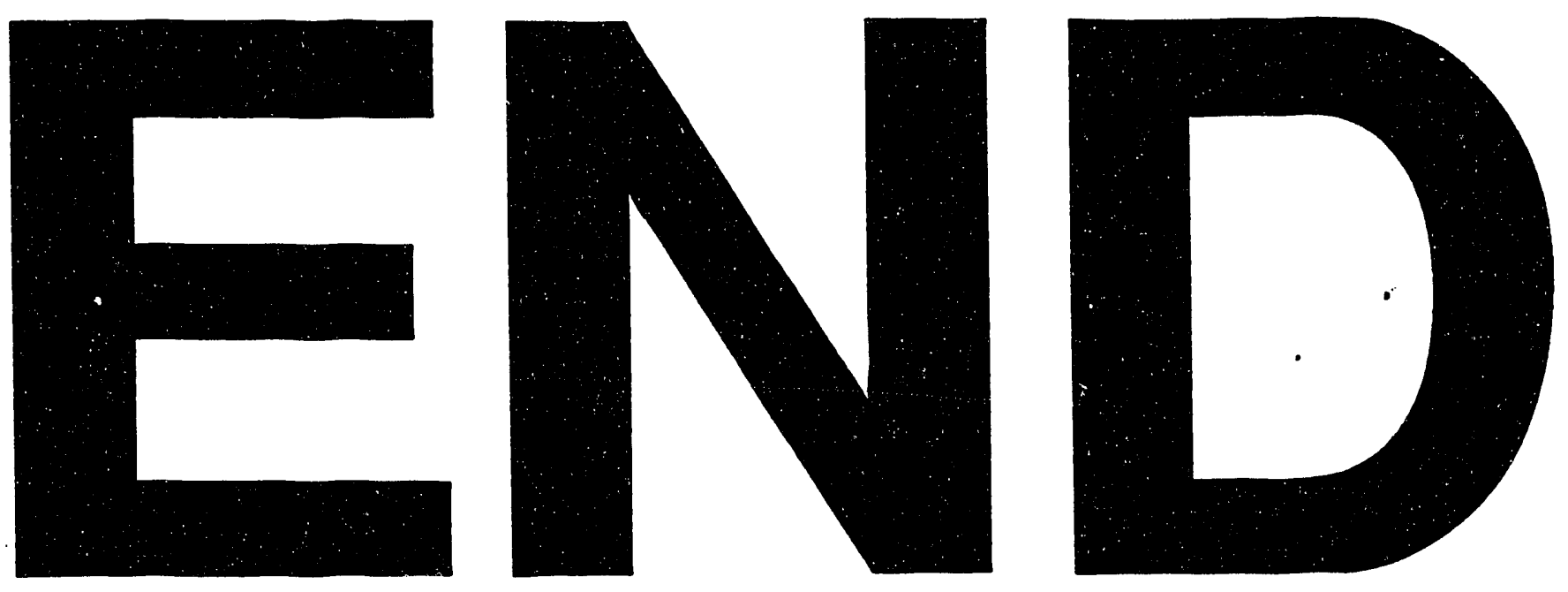
